\title{
Use of Information Sources and Knowledge of Child Sexual Abuse in Ogun State, Nigeria
}

\author{
Funke Omole, Rotimi Olatunji, Olusola Oyero, Nelson Okorie, Evaristus Adesina, \\ Received: November 25, 2019. Revised: June 17, 2020. Accepted: June 22, 2020. \\ Published: June 24, 2020.
}

\begin{abstract}
Child Sexual Abuse (CSA) constitutes a severe threat to the social well-being of not only children but extends to their families, societies. In response to the global challenge of reducing the growing effect of CSA, this study investigated the use of information sources on child sexual abuse in Ogun State. The study further tested two hypothesis to find out if communication channels for child sexual abuse education has no significant influence on the knowledge of the residents of Ogun State as well as Communication channels for child sexual abuse has no significant influence on the perception of residents of Ogun State. The study revealed that residents of Ogun state Nigeria depended on the internet as an information source for child sexual abuse. In addition, it was revealed that communication channels for child sexual abuse has significant influence on the knowledge and perception of the residents of Ogun State. Consequent upon these findings, the study recommends an urgent development of advocacy messages against CSA in form of edutainment, drama, songs that will fit the new media platform
\end{abstract}

Keywords: Communication, Information sources, Knowledge, Child Sexual Abuse, Nigeria

\section{INTRODUCTION}

Globally, sexual abuse is a major violence against rights of children, exerting psychological, emotional, physical, and social effects on victims. The United Nations Convention on the Rights of the Child (UNCRC) obliges member nations to protect rights of a child. Specifically, Articles 34 and 35 mandate states to protect children from all forms of sexual exploitation and sexual abuse, including coercion of a child to perform sexual activity, prostitution of children, and exploitation of children in pornography, abduction, sale, or trafficking of children [1]

This study was sponsored by Covenant University Centre for Research Innovation and Discoveries.

O. Omole is a Lecturer in the Department of Mass Communication at Covenant University, Ota $\quad$ Nigeria

R. Olatunji is a Professor of Mass Communication, Lagos State University, Nigeria

O. Oyero is an Associate Professor in the Department of Mass Communication, Covenant University, Ota Nigeria

N. Okorie is a Senior Lecturer in the Department of Mass Communication, Covenant University, Ota Nigeria

E. Adesina is a Lecturer in the Department of Mass Communication, Covenant University, Ota $\quad$ Nigeria

The World Health Organisation has described child sexual abuse as "the involvement of a child in sexual activity that he or she does not fully comprehend and is unable to give informed consent to, or for which the child is not developmentally prepared, or else that violate the laws or social taboos of society." [2]. Child Sexual abuse falls within the range of activities such as acts, forceful or otherwise, of inappropriate sexual solicitation, touching or fondling of genital, exposure of a child by an older person, oral intercourse, penetration through anal or vaginal as well as attempted intercourse [3].

Child Sexual Abuse (CSA) therefore constitutes a severe threat to the social well-being of not only children but extends to their families, societies. Africa which is the world's second largest continent and the second most populated continent after Asia [4] is also bedeviled by this dastardly act of Child Sexual Abuse. Reports have indicated that CSA vary across different countries on the African continent, depending on the country being researched on and the methodology adopted in the primary study, as well as the definitions [5], however there is a consensus that Africa could surpass other continents in incidences of Child sexual abuse as a result of several factors, ranging from cultural beliefs, patriarchal nature and rapid social change

The mass media has played a key role in the construction and framing of child abuse as a key social menace [6, 7]. Although before the 1960s, Child sex abuse was poorly attended to by the media, the narration has however increasingly changed, as the coverage of child abuse is reaching an optimum level. The media has examined the issue of CSA from standpoints of news programmes, edutainment, cartoons, TV drama, films, feature stories, call-in shows, interviews, soap operas among others means in a bid to reach a heterogeneous audience. The function of the media has also been noted to surround the groundwork of government agencies, nongovernmental organisations, professional bodies, activist as well as civil society agencies. In essence, rather than being the vanguard, the media is said to be a propagator of the different activities of these agencies. The groundwork for the recognition of child sexual abuse, for example, lay in early activities by feminists and survivors, and involved international links within the women's movement across the world.

The overall impact of the media in the exposure of citizens to child sex abuse has been considerable, even if it came late to the issue. With the increasing campaign against CSA however, this chapter seeks to find out the use of information sources on Child Sxual Abuse. of Nigerians on this social menace as propagated by the mass media in view of achieving the 2030 Sustainable Development Goals. 
Research Question

1. How do residents of Ogun State use information source on child abuse?

Hypothesis

H01: Communication channels for child sexual abuse education has no significant influence on the knowledge of the residents of Ogun State.

H02: Communication channels for child sexual abuse has no significant influence on the perception of residents of Ogun State.

\section{LITERATURE REVIEW}

\section{Child Sexual Abuse and Nigerian society}

Child Sexual Abuse is a menace that has eaten deep into the society's fabric. Many have become traumatized and a shadow of themselves as a result of this act [8]. Having the capability of scarring the individuals involved for the rest of their lives despite its perpetration for a short period, in some cases. Child Sexual Abuse is a burning issue in the society. As an integral aspect of the health and mental discourse, one can say that it is along the threshold of a major societal issue, an aspect the media is seen as a key player.

The media serve as the watchdog of the people (Lister, 2014) keeping them abreast of information and making members of the government accountable for their actions. However, in recent times, the media has delved into the role of sensitizing the populace on various societal issues. Issues on crime, rape, war, violence and so on have found their way into the media and its offerings and gained prominence. The media have found a way to promote or dispel a story based on the perception of its individuals and several other factors. Issues like CSA have also gained momentum over the past few years. However, it has been viewed from the angle of "criminal justice details of the specific incident rather than the contextual information about causes of and solutions to child sexual abuse, and prevention is rarely addressed' [9].

Through framing, the 'selection of a restricted number of thematically related attributes for inclusion on the media agenda when a particular object or issue is discussed' [10], the media has become an avenue where issues are ranked according to importance according to it. In the past, the news media have framed CSA as a crime perpetrated by strangers who drift into one-time contact with the children they molest, which perpetuates the "stranger danger" misconception $[6,7,11]$ when in fact, almost all CSA cases involve an adult with whom the child is familiar (Prevent Child Abuse America, 2005).

Nigerians have conducted studies on the media and their role in CSA. According to [12] in their study of the Perception and Practices of Parents in preventing child sexual abuse discovered that that many parents felt Child sexual Abuse was a common problem in the community, and most parents disagreed with common child sexual abuse myths. They also found out that almost all parents reported communicating with their child(ren) about stranger danger. However, about $47 \%$ of these parents felt their children could not be abused, and about $27.1 \%$ often left their children alone and unsupervised. There were no significant variations in the perceptions of child sexual abuse and communication practices.

Similarly, Awosola and Omoera [13] conducted studies on the view of child's right and the media in Edo state, their study revealed that even though the respondents claim to be well enlightened about CSA through the media, there are quite a number of incidences of abandoned babies, sexually abused or raped. In many more ways than one, this finding agrees with Ademokun (2002) who observed that "it is a common knowledge that children in Nigeria are bludgeoned into child labour and prostitution by highly placed persons under the guise of philanthropy". This is probably as a result of negligence or a carefree attitude from the audience in which such media contents were designed.

\section{CHILDREN, CHILDHOOD AND CHILD RIGHT}

Across a wide range of policies, fields and disciplines, the last series of decades have had children's rights occupy a significant place [14]. For such things as childhood, children and children's rights, there are no clear-cut definitions. For the purpose of this study however, we would be drawing on the considerations of the Convention on the Rights of the Child (CRC, 1989).

In most societies around the world, 'children' refer mostly to a set of individuals, set apart basically on the basis of their ages, which vary in most cases in line with cultural, economic and social circumstances. Article 1 of the CRC states that a child refers to every individual below the age of eighteen, except stated otherwise by the laws that bind and are applicable to such individual. This definition of children is not sacrosanct, but is strictly in line with the treaty. However, in most states and Nations of the world, this has become the norm, as childhood has become commonly defined to end at eighteen years of age [15] (Abramson; 1996, p.397; Cantwell, 2011).

Researchers like Joseph [16], Cornock and Montgomery [17] convene on arguments surrounding the beginning and end of childhood. With respect to where childhood begins, arguments abound as to the extent to which the rights of the child should apply to the unborn child. The end of childhood is equally laced with debates of its own, as researchers like Johnson, et al. [18] posit that the human brain develops fully at 25 years of age. This discovery notwithstanding, neuroscientists kick strongly against attributing maturity and human behavior to such conclusions as neurological processes. And while both sides maintain their different arguments, this singular discovery of a greater brain immaturity has resulted in a clamor that the child right protection be extended up until 25 years of age, as opposed to the initial 18 [19].

Childhood is more than just a passing phase in every child's life. As a matter of fact, childhood is historical, social and cultural. It is the combination of the former three aspects in the structural formation of a child's life and persona [20]. According to Vandenhole, et al. [14], this structural formation known as the 'youth moratorium' is characterized mainly by certain traits peculiar to children, which are determined largely 
by biological and psychological factors [21]. This 'youth moratorium', according to Vandenhole, et al. [14] can be viewed as the outcome of a historical process which follows that children become gradually alienated from the adult world, for the sole purpose of having them prepared for the adult life.

The most instrumental, legal document in children's rights is the CRC (1989). Binding on almost all states of the world, the treaty has laid down minimum standards on the rights of the child, for which the states can be held in question. There are four underlying principles of the $\mathrm{CRC}$; which are: nondiscrimination, best interests of the child, right to life, survival and development and participation. And like other rights in the world, children's rights are essential in order to achieve human dignity and social justice for children all over the world. There are several norms and beliefs that relate to children. In this case however, children's rights, such as issues that border on security or education are fundamental [14].

\section{CHILD RIGHT PROMOTION IN AFRICA}

1989 marked the beginning of a move in the right direction, as it was in this year that the Convention on the Rights of the Child (1989) by the General Assembly of the United Nations (UN) was adopted [22]. Prior to this event, there had been clamours for legal recognition as well as protection for the rights of children by different nations of the world. Shortly after the Convention on the Rights of the Child in 1989 was adopted, the African Charter on the Rights and Welfare of the Child was created and adopted by "the Assembly of Heads of State and Government of the Organisation of African Unity (OAU) in July 1990, and was brought into force in November 1999.'[22].

According to [23], the charter was brought about as a result of inadequacies which the convention failed to meet. These inadequacies were in respect to realities and happenings within the social, cultural and economic African world. It is pertinent to note however that both pieces of legislation complement one another, and do not oppose each other. Instead, the essence of the charter was mainly to incorporate African cultural values, beliefs, norms and experiences whilst considering issues that pertain to the rights of the African child.

In promoting the right of the African child, the charter consists of three different, broad parts. Within these parts are pegged the rights of the child and the provisions of the charter. The charter places enormous responsibilities on state parties who are expected to ensure that the necessary environment and machinery are in place in order to facilitate the enjoyment of rights, and the removal of any hindrances. And just like the convention, the charter also makes provisions for child protection, child right promotion and child welfare.

A number of criticisms have been levelled against the charter, ranging from the absence of any provision for the protection of the unborn child, with particular emphasis on issues of abortion [24], to the failure of the charter to make provisions for psychological recovery and social integration of children affected by armed conflict [25]. Other criticisms include financial handicap and insufficiency of nominees to constitute committee membership. Yet, in spite of all of these, the charter remains a veritable tool in enhancing the lives and promoting the rights of millions of African children. As a matter of fact, the charter remains a tool which can be used to advocate for children's rights, even at domestic levels.

\section{SOCIAL EFFECTS OF CHILD SEXUAL ABUSE}

Various forms of child sexual abuse abound, with the most common form being incest [26]. Across individuals, and cases, the impact of child sexual abuse varies [27]. The effects of CSA on the victim are also largely dependent on certain factors which are capable of increasing or reducing the effect of the damage felt by the individual. Such factors include, but are not limited to the individual's perspective, the individual's internal resources as well as the individual's level of support [28].

There are several social effects of CSA. The most common effect of CSA is depression [27]. In many cases, CSA survivors begin to internalize the abuse, holding negative thoughts about themselves. These thoughts range from worthlessness to having nothing to offer. These symptoms, Ratican [28] describes as feeling low, harbouring suicidal thoughts, irregular sleep patterns. Another major social effect of CSA is dissociation. For many CSA survivors, dissociating themselves in order to ensure their protection has become the order of the day. Some of them even carry this onto adulthood, using it as a coping mechanism whenever they feel threatened, or unsafe [29]. For survivors of CSA, dissociation may comprise moods of confusion, disorientation, nightmares, memories, as well as difficulty experiencing feelings. In addition to the aforementioned, another common social effect of CSA is difficulty often experienced in instituting interpersonal relationships. As a result of the traumatic event that plagued the victim's childhood, he or she may experience difficulties trusting others, and establishing interpersonal boundaries, and might even go as far as getting involved in abusive relationships.

\section{MEDIA COVERAGE OF CHILD SEXUAL ABUSE}

Research has it that in majority of cases, victims of child sexual abuse do not disclose, wilfully, their plight before attaining adulthood [8]. More than anything, this suggests that a large number of the affected population conceal and endure this traumatic event, failing to receive the much needed support. As earlier stated, the media has a huge role to play in the awareness, education, fight against stigmatization of CSA victims and a host of others. It is believed that with adequate media coverage of CSA, many will find their voices and speak up in event any abuse. This is what leads Bakare and Oyero [30] to assert that over the years, the media have become an important reference in profiling the importance of a child in the society. In similar fashion, Kitzinger [6] opines that the Media has significant influence on how society understands and approaches a problem. Dominant media can influence people regardless of their preferred stance or personal experience. This subsection seeks therefore to examine how the media have fared in their coverage of CSA.

To begin with, this study draws on framing as a method for measuring media coverage of CSA [11]. Here, media coverage of CSA stories in frames of rations are examined over the years. Not only is this method relevant to this study as a result of its 
explanation, interpretation and highlighting prowess, it is very useful when picking up important societal issues such that proper media roles are performed with regards to actuality in the process of reporting, proper definition of societal ills, accurate interpretations of events, with the sole aim of ensuring understanding, critical reasoning and evaluation and pushing for much needed solutions [30].

Prior to present day media, very little attention was given to CSA by the media. In Britain, as a matter of fact, the media did a good job of downplaying sexual crimes through heavy usage of euphemisms, allusions and the likes, failing to hit the nail on the head, and pinpoint the gravity of the sexual crime. Soon after, however, things took a turn in 1962, following a Henry Kempe publication, which publicized the term known as 'Battered Child Syndrome', which heralded ground breaking research, as well as prominent coverage CSA by the media [30]. It is within this period of time that celebrities like Oprah Winfrey opened up about having been victims of CSA [31,32].

\section{THEORETICAL FRAMEWORK}

\section{Uses and Gratification}

The uses and gratification theory explains the reason individuals use certain media and the benefit they get from them. In essence the theory helps examine, explain as well as provide answers to the reason people utilise certain media cum the benefits they derive from such $[33,34]$. This theory is quite essential for this study as it relates how the audiences perceive child sexual abuse content as propagated by the media and the effect such as on them to affecting their knowledge, attitude and practice.

\section{METHOD OF THE STUDY}

Survey method was employed to find out the use of information sources on CSA by residents of Ogun state. Three hundred copies of questionnaire were administered among residents of Abeokuta and Ota. While the former is the capital city of Ogun state, the latter is the industrial hub of the state. Data analysis took the combination of two major statistical analytical techniques namely: univariate and bivariate analysis. The univariate segment features descriptive statistics such as frequencies. This was used to assess the demographic and cultural characteristics of the respondents and the distribution of other important variables of the study. In the bivariate analysis, set of cross-tabulations were run in order to identify the patterns of relationship between selected background variables and conjugal relationship indices. Furthermore, the multiple regression analysis for the test Hypothesis formulated

\section{RESULT}

Research Question 1: How do residents of Ogun State use information source/on child sexual abuse?

\begin{tabular}{|c|c|c|c|}
\hline Information sources & Agree & Disagree & Undecided \\
\hline $\begin{array}{l}\text { Radio has provided me } \\
\text { information on Child } \\
\text { Sexual Abuse }\end{array}$ & $\begin{array}{l}233 \\
(77.7 .0 \%)\end{array}$ & $63(21.0 \%)$ & $4(1.3 \%)$ \\
\hline $\begin{array}{l}\text { Television programmes } \\
\text { have provided me } \\
\text { information on Child } \\
\text { Sexual Abuse }\end{array}$ & $249(83 \%)$ & $41(13.7 \%)$ & $10(3.3 \%)$ \\
\hline $\begin{array}{l}\text { Newspaper has provided } \\
\text { me information on Child } \\
\text { Sexual Abuse }\end{array}$ & $\begin{array}{l}213 \\
(71.0 \%)\end{array}$ & $63(21.0 \%)$ & $24(8.0 \%)$ \\
\hline $\begin{array}{l}\text { Leaflets/pamphlet/broch } \\
\text { ure/flyer/catalogue has } \\
\text { provided me information } \\
\text { on Child Sexual Abuse }\end{array}$ & $\begin{array}{l}168 \\
(56.0 \%)\end{array}$ & $\begin{array}{l}106 \\
(35.3 \%)\end{array}$ & $26(8.7 \%)$ \\
\hline $\begin{array}{l}\text { Internet/ website has } \\
\text { provided me information } \\
\text { on Child Sexual Abuse }\end{array}$ & $\begin{array}{l}258 \\
(86.0 \%)\end{array}$ & $36(12.0 \%)$ & $6(2.0 \%)$ \\
\hline $\begin{array}{l}\text { Health workers has } \\
\text { provided me information } \\
\text { on Child Sexual Abuse }\end{array}$ & $\begin{array}{l}188 \\
(62.7 \%)\end{array}$ & $78(26.0 \%)$ & $34(11.3 \%)$ \\
\hline $\begin{array}{l}\text { Colleague has given me } \\
\text { information about Child } \\
\text { Sexual Abuse }\end{array}$ & $191(63.7)$ & $60(20.0 \%)$ & $49(16.3 \%)$ \\
\hline $\begin{array}{l}\text { Neighbours has provided } \\
\text { me information about } \\
\text { Child Sexual Abuse }\end{array}$ & $\begin{array}{l}156 \\
(52.0 \%)\end{array}$ & $\begin{array}{l}112 \\
(37.3 \%)\end{array}$ & $32(10.7 \%)$ \\
\hline $\begin{array}{l}\text { Counselor has provided } \\
\text { me information about } \\
\text { Child Sexual Abuse }\end{array}$ & $\begin{array}{l}181 \\
(60.3 \%)\end{array}$ & $\begin{array}{l}104 \\
(34.7 \%)\end{array}$ & $15(5.0 \%)$ \\
\hline $\begin{array}{l}\text { Relative has provided me } \\
\text { information about Child } \\
\text { Sexual Abuse }\end{array}$ & $\begin{array}{l}156 \\
(52.0 \%)\end{array}$ & $99(33.0 \%)$ & $45(15.0 \%)$ \\
\hline \begin{tabular}{l}
\multicolumn{3}{l}{ Seminar/workshop/confe } \\
rence organized has \\
provided me information \\
about Child Sexual \\
Abuse
\end{tabular} & $\begin{array}{l}177 \\
(59.0 \%)\end{array}$ & $81(27.0 \%)$ & $42(14.0 \%)$ \\
\hline
\end{tabular}

When asked whether radio provided them information on child sexual abuse, $58.3 \%$ of the respondents simply agreed that radio provided them information on child sexual abuse, while $19.3 \%$ of the respondents strongly agreed. $77.6 \%$ of the respondents that perceived radio as information source/channels of child sexual abuse.

On if television programmes have provided them information on child sexual abuse, $52.7 \%$ of the respondents agreed, while $30.3 \%$ of the respondents strongly agreed. With regards to whether newspaper has provided them information on child sexual abuse. $53.3 \%$ of the respondents agreed that newspaper provided them information on child sexual abuse and $17.7 \%$ of the respondents strongly agreed. 
From the results of the study, $52.3 \%$ of the respondents agreed that internet provided them information on child sexual abuse and $33.7 \%$ of the respondents strongly agreed.

In addition, $38.0 \%$ of the respondents agreed that health workers provided them information on child sexual abuse, while $24.7 \%$ of the respondents strongly agreed.

When asked whether colleagues have given them information about child sexual abuse $49.7 \%$ of the respondents agreed that colleague provided them information about child sexual abuse and $14.0 \%$ of the respondents strongly agreed. Furthermore, $43.3 \%$ of the respondents agreed that neighbours provided them information about child sexual abuse and $8.7 \%$ of the respondents strongly agreed. $52 \%$ of the respondents that agreed and strongly agreed that neighbours provided them information on child sexual abuse, while $44.3 \%$ of the respondents agreed that counselor provided them information about child sexual abuse and $16.0 \%$ of the respondents strongly agreed. A total of $60.3 \%$ of the respondents agreed and strongly agreed that counselor provided them information on child sexual abuse.

The findings also revealed that $34.7 \%$ of the respondents agreed that relative provided them information about child sexual abuse and $17.3 \%$ of the respondents strongly agreed. Likewise $31.3 \%$ of the respondents agreed that seminar/conference organized provided them information about child sexual abuse and $27.7 \%$ of the respondents strongly agreed, making $59.0 \%$ of the respondents agreed and strongly agreed that seminar/conference organized provided them information about child sexual abuse.

Hence, it is clear that majority of the residents of Ogun State perceived internet and television programmes as information source that is useful on child sexual abuse.

\section{Hypothesis}

Ho1: Communication channels for child sexual abuse education has no significant influence on the knowledge of the residents of Ogun State.

Table 2: Model Summary

\begin{tabular}{|l|l|l|l|l|l|}
\hline Model & $\mathrm{R}$ & R Square & $\begin{array}{l}\text { Adjusted R } \\
\text { Square }\end{array}$ & $\begin{array}{l}\text { Std. Error of } \\
\text { the Estimate }\end{array}$ \\
\hline 1 & $.470^{\mathrm{a}}$ & .221 & .219 & 4.17166 \\
\hline
\end{tabular}

a. Predictors: (Constant), Communication Channels

b. Dependent Variable: knowledge

From the model summary table above, the value of $\mathbf{R}=\mathbf{0 . 4 7 0}$ (i.e. correlation coefficient ) shows that there is weak positive correlation between the communication channels and knowledge of the residents of Ogun State, the magnitude of both communication channels and knowledge of the residents increased in the same direction. The $\mathbf{R}$-squared $=\mathbf{0 . 2 2 1}$ (i.e. Coefficient of determination) means that $22.1 \%$ of the variation of knowledge can be explained by the model containing communication channels. This is quite low so predictions from the regression equation are fairly reliable, while $77.9 \%$ are due to random variables not considered in the model but is in the residual i.e. error term.

\section{Table 3: ANOVA $^{\mathrm{a}}$}

\begin{tabular}{|ll|l|l|l|l|l|}
\hline \multicolumn{2}{|l|}{ Model } & $\begin{array}{l}\text { Sum of } \\
\text { Squares }\end{array}$ & df & $\begin{array}{l}\text { Mean } \\
\text { Square }\end{array}$ & F & Sig. \\
\hline \multirow{4}{*}{1} & Regression & 1854.715 & 1 & 1854.715 & 106.576 & $.000^{\mathrm{b}}$ \\
& $\begin{array}{l}\text { Residual } \\
\text { Total }\end{array}$ & 6526.044 & 375 & 17.403 & & \\
& Total & 8380.759 & 376 & & & \\
\hline
\end{tabular}

a. Dependent Variable: knowledge

b. Predictors: (Constant), Communication Channels

From the anova table, since the sig $(0.000)<\alpha(0.05)$, we reject the null hypothesis and concluded that communication channels for child sexual abuse has significant influence on the knowledge of the residents of Ogun State.

Table 4: Coefficients ${ }^{\mathrm{a}}$

\begin{tabular}{|c|c|c|c|c|c|}
\hline \multirow[t]{2}{*}{ Model } & \multicolumn{2}{|c|}{$\begin{array}{l}\text { Unstandardized } \\
\text { Coefficients }\end{array}$} & $\begin{array}{l}\text { Standardized } \\
\text { Coefficients }\end{array}$ & \multirow[t]{2}{*}{$\mathrm{T}$} & \multirow[t]{2}{*}{ Sig. } \\
\hline & B & $\begin{array}{l}\text { Std. } \\
\text { Error }\end{array}$ & Beta & & \\
\hline (Constant) & 9.666 & 1.178 & & 8.208 & .000 \\
\hline $\begin{array}{l}1 \text { Communication } \\
\text { Channels }\end{array}$ & .308 & .030 & .470 & 10.324 & .000 \\
\hline
\end{tabular}

a. Dependent Variable: knowledge

From the coefficient table, the model below means that a unit increase in communication channels will lead to 0.308 increase in the knowledge of residents of Ogun State.

\section{Hypothesis two}

Ho2: Communication channels for child sexual abuse has no significant influence on the perception of residents of Ogun State.

Table 5: $\quad$ Model Summary

\begin{tabular}{|l|l|l|l|l|l|}
\hline Model & R & R Square & $\begin{array}{l}\text { Adjusted R } \\
\text { Square }\end{array}$ & $\begin{array}{l}\text { Std. Error of } \\
\text { the Estimate }\end{array}$ \\
\hline 1 & $.490^{\mathrm{a}}$ & .240 & .238 & 5.59757 \\
\hline
\end{tabular}

a. Predictors: (Constant), Communication Channels

b. Dependent Variable: Perception

From the model summary table above, the value of $\mathbf{R}=\mathbf{0 . 4 9 0}$ (i.e. correlation coefficient ) shows that there is weak positive correlation between the communication channels and perception of the residents of Ogun State, the magnitude of both communication channels and knowledge of the residents increased in the same direction. The R-squared $=\mathbf{0 . 2 4 0}$ (i.e. Coefficient of determination) means that $24.0 \%$ of the variation of perception can be explained by the model containing communication channels. This is quite low so predictions from the regression equation are fairly reliable, while $76.0 \%$ are due 
to random variables not considered in the model but is in the residual i.e. error term.

Table 6: $\quad$ ANOVA $^{\mathrm{a}}$

\begin{tabular}{|ll|l|l|l|l|l|}
\hline Model & $\begin{array}{l}\text { Sum of } \\
\text { Squares }\end{array}$ & Df & $\begin{array}{l}\text { Mean } \\
\text { Square }\end{array}$ & F & Sig. \\
\hline & Regression & 3714.583 & 1 & 3714.583 & 118.553 & $.000^{\mathrm{b}}$ \\
1 & Residual & 11749.788 & 375 & 31.333 & & \\
& Total & 15464.371 & 376 & & & \\
\hline
\end{tabular}

a. Dependent Variable: perception

b. Predictors: (Constant), Communication Channels

From the anova table, since the sig $(0.000)<\alpha(0.05)$, we reject the null hypothesis and concluded that communication channels for child sexual abuse has significant influence on the perception of the residents of Ogun State.

Table 7: Coefficients $^{\mathrm{a}}$

\begin{tabular}{|ll|l|l|l|l|l|}
\hline Model & \multicolumn{2}{|l|}{$\begin{array}{l}\text { Unstandardize } \\
\text { d Coefficients }\end{array}$} & $\begin{array}{l}\text { Standardi } \\
\text { zed } \\
\text { Coefficie } \\
\text { nts }\end{array}$ & T & Sig. \\
\cline { 2 - 5 } & B & $\begin{array}{l}\text { Std. } \\
\text { Error }\end{array}$ & Beta & & \\
\hline 1 & $\begin{array}{l}\text { (Constant) } \\
\text { Communication } \\
\text { Channels }\end{array}$ & $\begin{array}{l}14.8 \\
.436\end{array}$ & .040 & .490 & 10.88 & .000 \\
\hline
\end{tabular}

a. Dependent Variable: perception

From the coefficient table, the model below means that a unit increase in communication channels will lead to 0.436 increase in the perception of the residents of Ogun State.

\section{DISCUSSION OF FINDINGS}

Regarding audience perception of child sexual abuse media campaigns in Nigeria, majority of the respondents indicated that the use of internet and broadcast media have been their major source of information on child sexual abuse (CSA). This is in support of the Uses and Gratification theory that people utilise certain media because of the benefits they derive from such (Gallion, 2010; Wimmer and Dominick, cited in Asemah, 2011).

The findings also show that the internet, broadcast and print media were significant in the coverage and reportage of information on the child sexual abuse. This finding also support previous study that with adequate media coverage of CSA, many will find their voices and speak up, in event of any abuse. This is what led Bakare and Oyero [35] to assert that over the years, the media have become an important reference in profiling the importance of a child in the society.

It is to be pointed out that the media such as broadcast media and internet have increased users' pursuit of uses and gratification theory. This outcome reaffirms the tenet that new technology has increased the number of choices and how people selectively choose from media fare by avoiding dissonance and seeking consonance based on interests.

The first hypothesis which stated that, communication channels for child sexual abuse education has no significant influence on the knowledge of the residents was rejected. Correlation analysis on figure 2 shows that there is weak positive correlation between the communication channels and knowledge of the residents, the magnitude of both communication channels and knowledge of the residents increased in the same direction but figure 3 showed that communication channels for child sexual abuse have significant influence on the knowledge of residents.

This study confirmed that mass media channels and internet constitute the primary sources of information and could significantly influenced child sexual abuse knowledge. Also, the fact that mass media are important in promoting messages on sexual abuse cannot be ignored.

The second hypothesis which stated that communication channels for child sexual abuse has no significant influence on the perception of residents was rejected. From the available data on table 5 which shows that there is weak positive correlation between the communication channels and perception of the residents, the magnitude of both communication channels and knowledge of the residents increased in the same direction but figure 6 reflect that communication channels for child sexual abuse has significant influence on the perception of residents. This study has showed that exposure to communication channels has an impact on the perception of child sexual abuse campaigns.

\section{CONCLUSION}

Child Sexual Abuse is a major bane affecting children in many Africa countries including Nigeria. Due to the rise in Child Sexual Abuse there is need for increased media campaigns and awareness. The knowledge of child sexual abuse is no news as findings showed that audience are aware of the problem of the abuse. Therefore it is right to conclude from findings that the issue of child sexual abuse is not awareness, as the result showed that the media is the major source of information about child sexual abuse among others. Results showed that audience have a good enlightened perception about child sexual abuse and media campaigns on CSA. Although it is still disturbing that the knowledge of child right acts is still lacking. This study concludes that the lack of knowledge about child right acts may be the reason for the ineffectiveness in finding solution to the problem of Child sexual Abuse. 


\section{RECOMMENDATIONS}

In order to improve audience awareness and increase their perception of child sexual abuse media campaign. The following recommendations are critical:

1. Media campaigns should focus more on encouraging people to report abuse.

2. The media should extensively give more information and education on the issue of child rights act and its provisions.

\section{REFERENCES}

[1] UNICEF, "Convention on the Rights of the Child," 1989.

[2] WHO, "Guidelines for medico-legal care of victims of sexual violence," 2003.

[3] A. Butchart, A. Phinney Harvey, M. Mian, T. Furniss, T. Kahane, and W. H. Organization, "Preventing child maltreatment: a guide to taking action and generating evidence," 2006.

[4] P. Gerland, A. E. Raftery, H. Ševčíková, N. Li, D. Gu, T. Spoorenberg, et al., "World population stabilization unlikely this century," Science, vol. 346, pp. 234-237, 2014.

[5] N. Pereda, G. Guilera, M. Forns, and J. Gómez-Benito, "The international epidemiology of child sexual abuse: A continuation of Finkelhor (1994)," Child abuse \& neglect, vol. 33, pp. 331-342, 2009

[6] J. Kitzinger, Framing abuse: Media influence and public understanding of sexual violence against children: Pluto Press, 2004

[7] J. Kitzinger and P. Skidmore, "Playing safe: Media coverage of child sexual abuse prevention strategies," Child Abuse Review, vol. 4, pp. 47-56, 1995.

[8] R. Alaggia, "Disclosing the trauma of child sexual abuse: A gender analysis," Journal of loss and trauma, vol. 10, pp. 453-470, 2005.

[9] P. Mejia, A. Cheyne, and L. Dorfman, "News coverage of child sexual abuse and prevention, 2007-2009," Journal of Child Sexual Abuse, vol. 21, pp. 470-487, 2012.

[10] E. A. Griffin, A first look at communication theory/Em Griffin: New York: McGraw-Hill, 2012.

[11] R. E. Cheit, Y. Shavit, and Z. Reiss-Davis, "Magazine coverage of child sexual abuse, 1992-2004," Journal of child sexual abuse, vol. 19, pp. 99-117, 2010.

[12] O. K. Ige and O. I. Fawole, "Preventing child sexual abuse: parents' perceptions and practices in urban Nigeria," Journal of child sexual abuse, vol. 20, pp. 695-707, 2011.

[13] R. K. Awosola and O. S. Omoera, "Child rights and the media: The Nigerian experience," Studies on Home and Community Science, vol. 2, pp. 125-131, 2008.

[14] W. Vandenhole, E. Desmet, D. Reynaert, and S. Lembrechts, Routledge international handbook of children's rights studies: Routledge, 2015.

[15] B. Abramson, "The invisibility of children and adolescents," Monitoring Children's Rights. The Hague, Boston, MA and London: Martinus Nijhoff, pp. 393-402, 1996.

[16] R. Joseph, Human rights and the unborn child: Brill, 2009.

[17] M. Cornock and H. Montgomery, "Children's rights in and out of the womb," Int'l J. Child. Rts., vol. 19, p. 3, 2011.

[18] S. B. Johnson, R. W. Blum, and J. N. Giedd, "Adolescent maturity and the brain: the promise and pitfalls of neuroscience research in adolescent health policy," Journal of Adolescent Health, vol. 45, pp. 216-221, 2009

[19] P. Veerman, "The Ageing of the UN Convention on the Rights of the Child," The International Journal of Children's Rights, vol. 18, pp. $585-618,2010$

[20] E. Verhellen, Convention on the rights of the child: background, motivation, strategies, main themes: ERIC, 2000.

[21] J. Zinnecker, "Childhood and adolescence as pedagogic moratoria," Zeitschrift Fur Padagogik, pp. 36-68, 2000.

22] D. Olowu, "Protecting children's rights in Africa: a critique of the African Charter on the Rights and Welfare of the Child," Int'l J. Child. Rts., vol. 10, p. 127, 2002.

$$
\begin{aligned}
& \text { Y. Bakare and O. Oyero, "PARENTS'PERCEPTION OF MEDIA } \\
& \text { REPORTS ON CHILD SEXUAL ABUSE A STUDY OF OTA, } \\
& \text { OGUN STATE," } 2017 .
\end{aligned}
$$

\section{Creative Commons Attribution License 4.0 (Attribution 4.0 International, CC BY} 4.0)

This article is published under the terms of the Creative Commons Attribution License 4.0 https://creativecommons.org/licenses/by $/ 4.0 /$ deed.e $\underline{\text { n_US }}$ 